\title{
フェライト埋め込みガラスセラミック複合基板型 サーキュレータの開発
}

\author{
冥加 修*, 生稲 一洋*, 金子 友哉**, 古谷 充*, 岡田 芳嗣*
}

\section{Development of Complex-Substrate-Type Circulator with Ferrite Column Embedded in Glass-Ceramic}

Osamu MYOHGA*, Kazuhiro IKUINA*, Tomoya KANEKO**, Mitsuru FURUYA* and Yoshitsugu OKADA*

\footnotetext{
*日本電気株式会社機能材料研究所（テ216-8555＼cjkstart神奈川県川崎市宮前区宮崎4-1-1）

**日本電気株式会社マイクロ波衛星通信事業部（テ224-8555＼cjkstart神奈川県横浜市都筑区池辺町4035）

*Functional Material Laboratories, NEC Corp. (4-1-1 Miyazaki, Miyamae-ku, Kawasaki-shi, Kanagawa 216-8555)

* * Microwave and Satellite Communications Division, NEC Corp. (4035 Ikebe-cho, Tsuzuki-ku, Yokohama-shi, Kanagawa 224-8555)
}

\begin{abstract}
概要 ガラスセラミック (GC) に円板状フェライトを埋め込んだ複合基板型サーキュレータ (CIR) を開発した。本CIR は，直径 $1.7 \mathrm{~mm}$, 厚さ $0.25 \mathrm{~mm}$ の Ni-Znフェライト円板をGCに埋め达み，一方の面に $30 \mathrm{GHz}$ 付近で動作するように設計した信 号回路, 他方の面にグラウンドを印刷技術で形成した一辺 $3 \mathrm{~mm}$ の寸法形状である。印刷用導体材料として Au, Ag, Ag-Pd を使用し, 信号回路の円形導体部直径 $1.26 \mathrm{~mm} \sim 1.54 \mathrm{~mm}$ の 5 種類を作製し周波数特性を測定した。その結果, 安価なAg導体 材料を使用して円形導体部直径 $1.33 \mathrm{~mm}$ で择入損失 $0.5 \mathrm{~dB}$ 実現した。本CIRは温度サイクル試験 $\left(-55^{\circ} \mathrm{C} \sim 125^{\circ} \mathrm{C}\right)$ の結果, 1000サイクル以上で信号回路の破断や構成材料の破壞は起こらなかった。Coffin-Manson's Lawから模擬的に寿命を見皘もる と，58年以上の予測寿命を算出した。
\end{abstract}

\begin{abstract}
Reported here is the development of a complex-substrate-type circulator (CIR) with a ferrite column embedded in glass-ceramic (GC). The CIR, designed to operate at about $30 \mathrm{GHz}$, is 3 $\mathrm{mm}$ square. We started with a GC substrate embedded with a Ni-Zn ferrite column $(1.7 \mathrm{~mm}$ diameter), and on this we tested 3 possible conductive materials (Au, Ag, Ag-Pd) and 5 different diameter, ranging from $1.26 \mathrm{~mm}$ to $1.54 \mathrm{~mm}$, for the circular center conductor area. The lowest insertion loss $(0.5 \mathrm{~dB})$ was achieved with $\mathrm{Ag}$ at a diameter of $1.33 \mathrm{~mm}$. TemperatureCycle-Test $\left(-55^{\circ} \mathrm{C}\right.$ to $\left.125^{\circ} \mathrm{C}\right)$ over more than 1000 cycles, this combination also suffered neither breaks in circulator circuits nor any cracking in any of the component materials. According to Coffin-Manson's Law, this would correspond to an estimated life span of 58 years.
\end{abstract}

Key Words: Circulator, Isolator, Complex-Substrate-Type, Glass Ceramic, Ni-Zn Ferrite

\section{1. はじめに}

ミリ波帯を使用した無線通信の各種方式が国内外で具体 的に提案され, 各種部品の低損失化, および高周波化に伴 う小型化を狙った部品開発が活発になっている。

ミリ波部品の 1 つとして，すでに市販されている CIR/ISO（サーキュレータ/アイソレータ）は，軟磁性フ エライト基板に印刷技術あるいはめっき技術により $\mathrm{Au}$ 導 体を形成したものである。しかしながら，フェライトは高 周波化と共に損失の増大がGC（ガラスセラミック）より 大きいという欠点がある。

著者らは, 動作周波数 $30 \mathrm{GHz}$ 帯 $\mathrm{CIR}$ の損失の低減を狙っ て，低温焼成のGCに円板状Ni-Znフェライトを埋め込んだ 構造の複合基板を作製した。その基板の片面にCIRの信号 （SIG）回路，他面にグラウンド（GND）を印刷技術で形 成した。この構成は，MSLのほとんどがGC基板上に配線
されるため, 上記したフェライト基板型に比べて損失が小 さくなると期待できる。また，実装基板として使用される アルミナ基板（熱膨張係数 $\alpha ; 5.7 \mathrm{ppm} /{ }^{\circ} \mathrm{C}$ ) とフェライト $\left(\alpha ; 9.9 \mathrm{ppm} /{ }^{\circ} \mathrm{C}\right)$ は熱膨張差が大きく, フェライトと実装 基板をろう付けすると，ろう付け作業あるいは長期間の温 度変化によってフェライトに割れが発生した。しかしなが ら，フェライトをGC基板に埋め込んだ本報告の構成は， GCと実装基板の熱膨張係数がほぼ同等であるために，GC 基板に割れが発生しないことが期待できる。

本報告は，導体に使用する材質およびSIG回路の円形導 体部直径の最適化とインピーダンス整合等により最適構成 としたCIRの周波数特性, および上記構成のCIRを温度サ イクル試験により信頼性評価した結果を報告する。

\section{2. サーキュレータの構成および作製方法}

フェライト埋め込みGC基板（3mm $\square-0.25 \mathrm{~mm} ）$ にSIG 


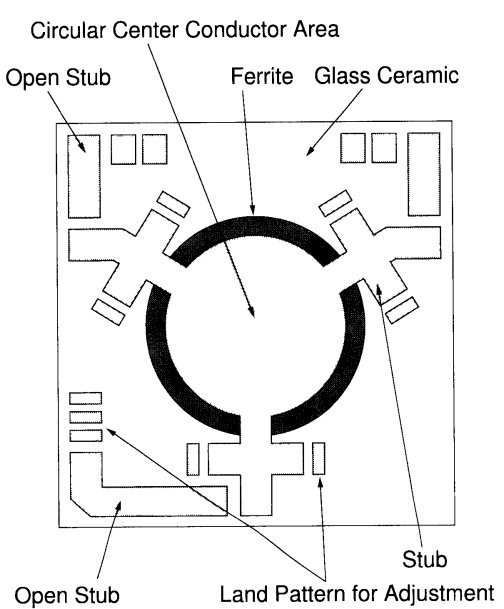

Fig.1 Schematic of the developed complex circulator
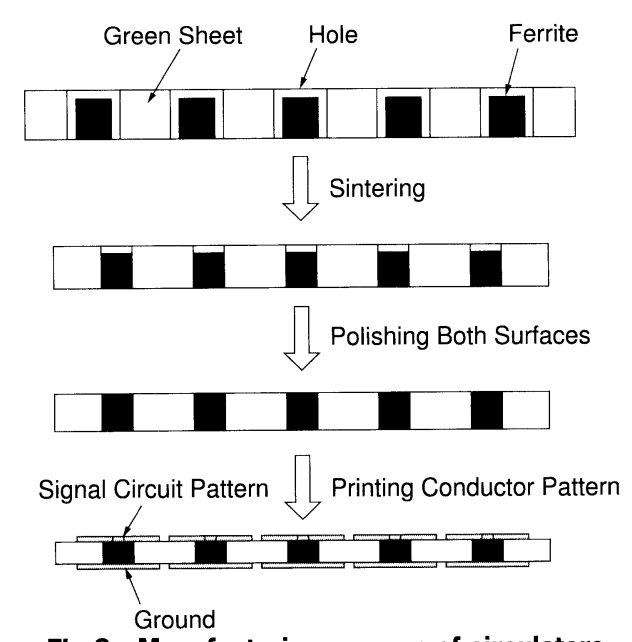

Fig.2 Manufacturing process of circulators

回路を形成したCIRの平面図をFig. 1 に示す。円形導体部 から 120 度の等角度でMSLを引き出し, 各々のMSLにイン ピーダンス整合用スタブと微調用ランド，ISO用途の際に

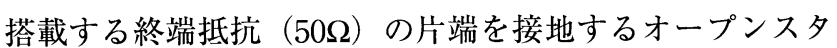
ブと微調用ランドを形成した。

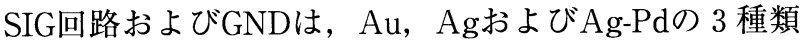
の導体ペーストを使用した。

このCIRは, グリーンシートの穴あけ加工および積層後, Fig. 2 に示すようにフェライト（直径 $1.7 \mathrm{~mm}$ ）を配置後焼 成し，その複合焼成体を両面研磨してその研磨面に導体印 刷後導体焼き付けするプロセスで作製した。1つの基板に は25個（5 行 5 列）のCIR/ISOを配列した。

\section{3. 測定方法}

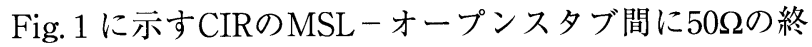
端抵抗を $\mathrm{Au}-\mathrm{Sn}$ 万う材で接続してISOとし， $\mathrm{S}_{11}, \mathrm{~S}_{22}$ (反射 損失), $\mathrm{S}_{12}$ (アイソレーション) および $\mathrm{S}_{21}$ (挿入損失) の Sパラメータを $20 \mathrm{GHz} \sim 40 \mathrm{GHz}$ の周波数範囲で測定した。

測定には，HP製ネットワークアナライザ（8510C）お よびアンリッ製フィクスチャ（3680V）と治具を使用し， CIR/ISOをFig. 3 に示す構成でフィクスチャに接続した。 CIR上方には $0.2 \mathrm{~mm}$ のギャップを設けて直径 $1.75 \mathrm{~mm}$ - 長

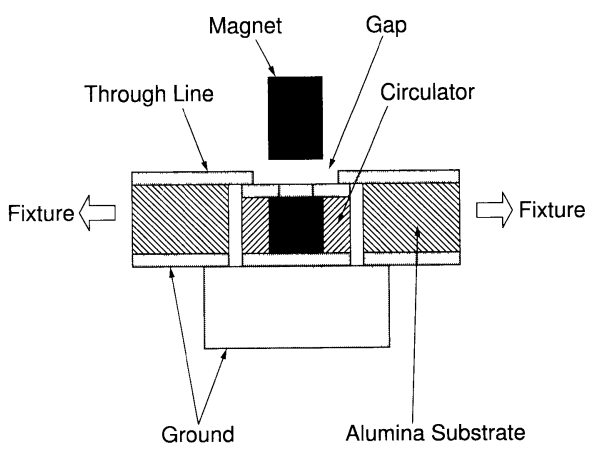

Fig.3 Composition for measuring circulator

さ $4 \mathrm{~mm}$ のマグネット（$\left(\mathrm{B}_{\mathrm{r}}=5000 \mathrm{G} ）\right.$ を配置した。

\section{4. サーキュレータSIG回路の設計}

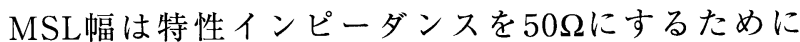
$0.25 \mathrm{~mm}$ とした。

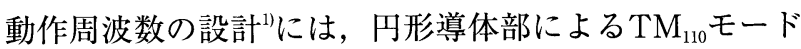
共振（ $\mathrm{f}_{1}$ ) と埋め込まれた円板フェライトによる $\mathrm{TM}_{110}$ モ 一ド共振 $\left(\mathrm{f}_{2}\right)$ を考虑し，この 2 つの共振が結合するモデ ルを使用した。 $\mathrm{f}_{1}$ はオールフェライト基板における動作周 波数と一致するもので，式(1)（фは円形導体部直径）によ り求めた。 $\mathrm{f}_{2}$ は式(1)の垤埋め込みフェライトの直径（D) を代入して求めた。

$$
f_{1}=\frac{1.84}{\phi \pi \sqrt{\mu_{0} \mu_{\text {eff }} \varepsilon_{0} \varepsilon_{\text {eff }}}} \cong \frac{177}{\phi \sqrt{\varepsilon_{r}}}=\frac{177}{\phi \sqrt{14}}(G H z)
$$

ただし， $\mu_{0}, \mu_{\text {eff }}$ は各々真空の透磁率，実効透磁率， $\varepsilon_{0}$, $\varepsilon_{\text {eff }}$ は各々真空の誘電率, 実効誘電率, $\varepsilon_{\mathrm{r}}$ は比誘電率である。 結合共振モード周波数 $\mathrm{f}_{0}$ は, これらの 2 つ共振周波数 $\mathrm{f}_{1}, \mathrm{f}_{2}$ より以下の式(2)から算出した。

$$
f_{0}=\sqrt{f_{1} \cdot f_{2}}
$$

円板フェライト直径をパラメータとし，算出した動作周 波数vs円形導体直径の関係をFig. 4 に示す。

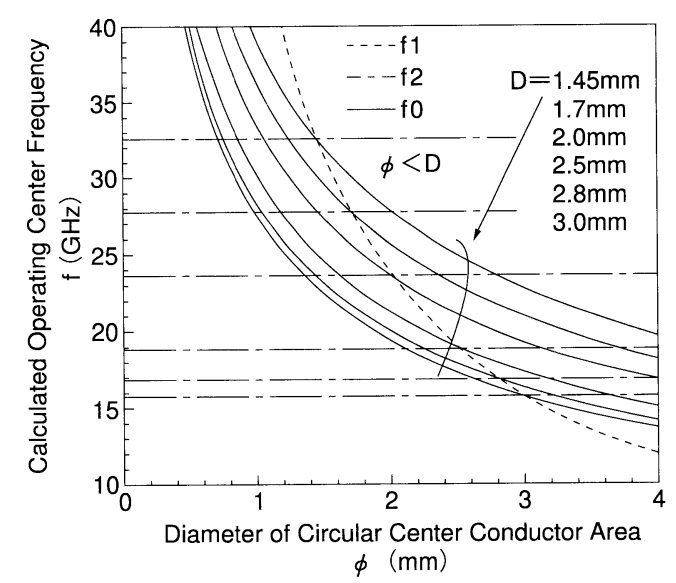

Fig.4 Relation between calculated operating center frequency and diameter of circular center conductor area 
Table 1. Diameter of circular center conductor area

\begin{tabular}{c|c|c|c|c|c}
\hline Types & $\mathrm{a}$ & $\mathrm{b}$ & $\mathrm{c}$ & $\mathrm{d}$ & $\mathrm{e}$ \\
\hline Diameter $(\mathrm{mm})$ & 1.54 & 1.47 & 1.40 & 1.33 & 1.26 \\
\hline
\end{tabular}

同図から，動作周波数 $30 \mathrm{GHz}$ に対する円形導体部直径を $1.40 \mathrm{~mm}$ とし，その前後10\%の範囲で 5 種類（Table 1 ) のCIR/ISOを作製した。なお，フェライト直径 $\mathrm{D}=1.7 \mathrm{~mm}$ である。

\section{5. アイソレータ特性}

本報告のCIRはFig. 1 の下側のMSL-オープンスタブ間

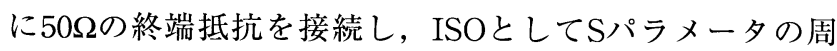
波数特性を測定した。

\section{1 導体材質と円形導体部直径の最適化}

3 種類の導体材質で各 5 種類の直径の円形導体部を形成 したCIR/ISOについて，Sパラメータの周波数特性を測定 し， $\mathrm{S}_{21}$ の最小值を円形導体部直径に対してプロットした (Fig. 5 )。

$\mathrm{S}_{21}$ は導体材質の電気抵抗率の大小に対応しており，何 れの導体材質においても， $\mathrm{S}_{21}$ は，円形導体部直径が $1.54 \mathrm{~mm}$ から $1.26 \mathrm{~mm}$ に減少すると共に〔フェライト直径 （1.7mm）より小さくなるにつれて〕減少する傾向が見ら れる。

$\mathrm{Au}$ と Agは $\phi=1.33 \mathrm{~mm}$ と $1.26 \mathrm{~mm}$ でほぼ同等の值である。 したがって, 低コストの観点から導体材質としてAgが適 切である。

$\mathrm{Ni}-\mathrm{Zn}$ フェライトと GCの損失を比較するために $3 \mathrm{~mm} \square$, 厚さ $0.25 \mathrm{~mm}$ の GC基板と $\mathrm{Ni}-\mathrm{Zn}$ フェライト基板に $\mathrm{Ag}$ 導体で 長さ $3 \mathrm{~mm}$ ，幅 $0.25 \mathrm{~mm}$ のSLを形成したスルー基板を同 一方法で測定し, $30 \mathrm{GHz}$ でフェライトの損失の方が $0.34 \mathrm{~dB}$ 大きいことを確認した。したがって, 円形導体部直径がさ らに小さくなるとフェライト上のMSLの損失が増大し， 挿入損失は増加すると考えられる。すなわち，フェライト 基板型CIR/ISOはフェライト上にMSLが形成されている ため， $\mathrm{S}_{21}$ は複合基板型より大きくなる。このことから， 本報告のCIR/ISOは低損失化に適した構成である。

\subsection{Sパラメータの周波数特性}

Table 1 に示すCIRタイプd (円形導体部直径 $\phi=1.33 \mathrm{~mm}$ ) は，所望の周波数範囲でタイプeより優れた周波数特性を

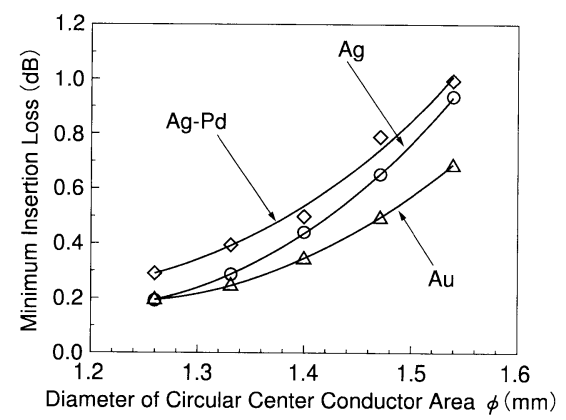

Fig.5 Relation between measured minimum insertion loss and diameter of circular center conductor area
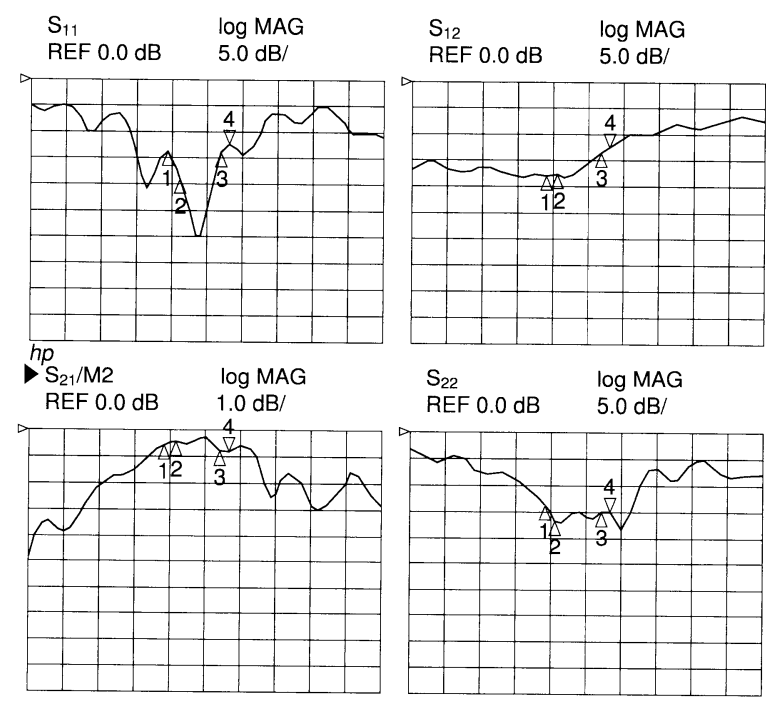

START $20.000000000 \mathrm{GHz}$

STOP $40.000000000 \mathrm{GHz}$

Fig.6 S-parameter characteristics of the developed circulator

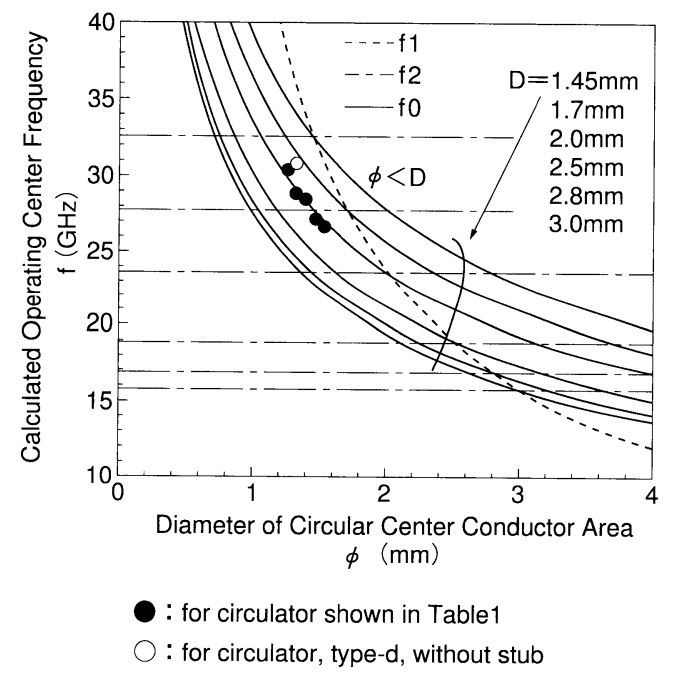

Fig.7 Relation between calculated operating center frequency and diameter of circular center conductor area

有しており，その特性をFig. 6 に示す。 $27 \mathrm{GHz} \sim 32 \mathrm{GHz}$ の 周波数範囲（送受信に使用する帯域）に注目すると, 無調 整であるにもかかわらず $\mathrm{S}_{11}, \mathrm{~S}_{22}$ 抢よび $\mathrm{S}_{12}$ とも $15 \mathrm{~dB}$ 程度を

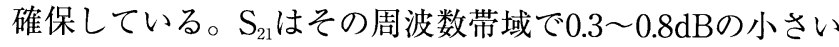
值が得られた。

\section{3 設計值と実測值の対応}

$\mathrm{Ag}$ 導体を使用した 5 種類の円形導体部直径のCIRの動 作周波数（実測值）を，モデル計算したFig. 4 のグラフ上 にの印でプロットすると（Fig. 7 )，フェライト直径 $2.0 \mathrm{~mm}$ の曲線近傍に沿って変化していることがわかる。円 形導体部直径 $1.33 \mathrm{~mm}$ のCIRについて，3つのMSLに形成 したスタブを除去すると，動作周波数が $2 \mathrm{GHz}$ 程度増加し (○印), フェライト直径 $1.7 \mathrm{~mm}$ の曲線近傍に移動した。こ のことから，2つの共振が結合するモデルを使用した動作 周波数vs円形導体部直径の計算は，MSLにスタブを形成 しないCIR/ISOのSIG回路構成に適用できることがわかっ た。したがって，スタブ形成等でインピーダンス整合によ 

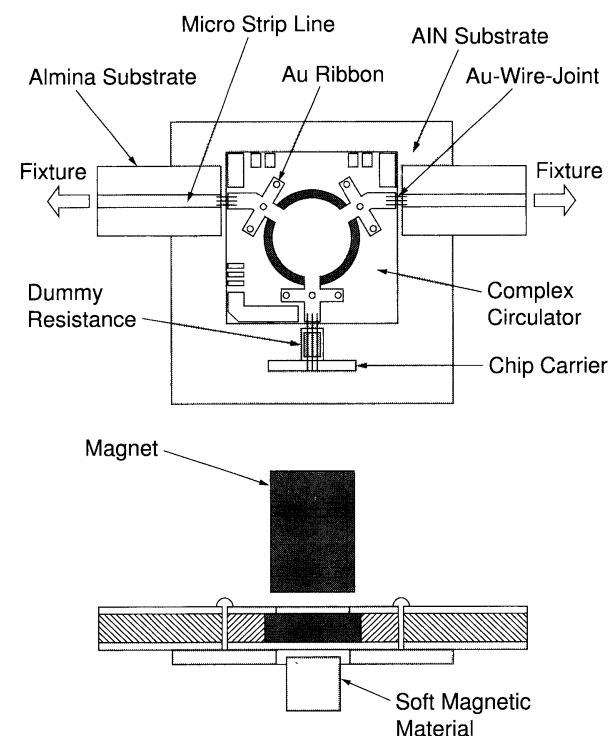

Fig.8 Composition of the adjusted circulator on AIN substrate, similar to actual loading

る周波数変化を考慮すると, 所望の周波数で使用する CIR/ISOの円形導体部直径をおおむね計算で求めることが できる。

\section{6. 調整したサーキュレータの周波数特性}

CIRのAg導体にAuめっきを施し, Fig. 8 に示すように ランドを利用してAuリボンをボンディングしてスタブ長 を調整したCIR/ISO，MSLを形成したアルミナ基板およ び終端抵抗とチップキャリアを, 表面がAuめっきされた $\mathrm{AlN}$ 基板にAu-Snろう材で接合しGNDを共通にして配置し た。SIG回路はAuワイヤボンディングで接続した。

CIRの下方に直径 $1.7 \mathrm{~mm}$, 長さ $0.4 \mathrm{~mm}$ の軟磁性材料を $0.1 \mathrm{~mm}$ のギャップを設けて配置し，上方に前述と同様のマ グネットを0.1mmのギャップを設けて配置した。これをフ イクスチャにセットしてアイソレータ特性を測定した。そ の結果をFig. 9 に示す。

Fig. 9 の測定結果を読み取り, 挿入損失 $0.5 \mathrm{~dB}$ 以下, ア イソレーションおよび反射損失 $15 \mathrm{~dB}$ 以上の周波数帯域幅 をTable 2 に示す。

同表からわかるように, 各項目の周波数帯域幅は, 無調 整のCIRの特性（Fig. 5 ）に比べて著しく改善されている ことがわかる。

\section{7. 信頼性}

本報告のCIR/ISOは熱膨張係数の異なる GC, フェライ トおよびAg導体を使用しているため, 温度変化による各 部材の割れや破断が起こることが考えられ，信頼性確認の ためにCIR/ISO単体およびFig. 8 のように構成した

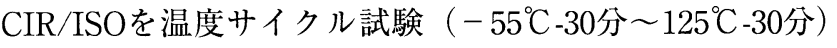
した。その結果，1055回の試験後において，十分なISO特 性を示し, 部材の割れや断線がないことを確認した。この 結果は, 金属の塑性変形に対する疲労に関するCoffin-

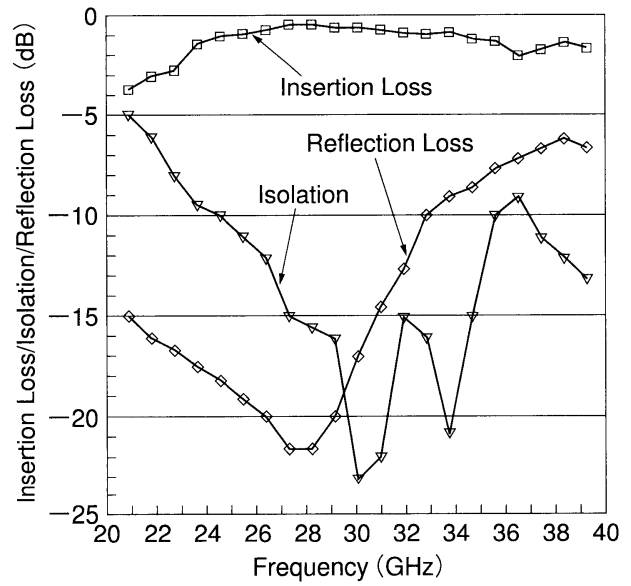

Fig.9 Microwave characteristics of the adjusted circulator

Table 2. Properties of the adjusted circulator

\begin{tabular}{c|c|c}
\hline Request Properties & $\begin{array}{c}\text { Frequency Width } \\
(\mathrm{GHz})\end{array}$ & $\begin{array}{c}\text { Best Value } \\
(\mathrm{dB})\end{array}$ \\
\hline $\begin{array}{c}\text { Insertion Loss } \\
\text { (below 0.5 dB) }\end{array}$ & 4.7 & 0.3 \\
\hline $\begin{array}{c}\text { Isolation } \\
\text { (above 15 dB) }\end{array}$ & 10.6 & 22 \\
\hline $\begin{array}{c}\text { Return Loss } \\
\text { (above 15 dB) }\end{array}$ & 7.9 & 23 \\
\hline
\end{tabular}

Manson's $\mathrm{Law}^{2)}$ (式 3 ） から模擬的に寿命を見積もると， 58年以上の予測寿命（Y）を算出した。

$$
Y=\left(\frac{\Delta T 1}{\Delta T 2}\right)^{2} \times \frac{\Delta C 1}{\Delta C 2 \cdot d} \quad \text { (年) }
$$

ただし， $\Delta T 1$ は試験の温度差 $\left(180^{\circ} \mathrm{C}\right) ， \Delta T 2$ はイール ドを想定した温度差，C1は試験温度サイクル数 (1055)， C2はフィールドで想定した一日の温度サイクル数 ( 1 回), $d$ は 1 年の日数（365日）を示す。

\section{8. まとめ}

小型，低損失および高信頼性のCIR/ISOを開発した。以 下に主な成果を述べる。

(1)Ag導体で回路を印刷形成し，その表面にAuめっきし たCIR/ISOを作製し，30GHzで挿入損失 $0.5 \mathrm{db}$ 以下実現 した。

(2)SIG回路の円形導体部直径は，2つのTM110モード共 振が結合するモデルから概略算出できた。

(3)上記CIR/ISOは，温度サイクル試験 $\left(-55^{\circ} \mathrm{C} \sim 125^{\circ} \mathrm{C}\right)$ で1055回後も十分なISO特性を示し，高信頼性を有するこ とがわかった。

(1999.9.24-受理２000.1.17-再受理）

\section{文献}

1) 岡田文明：“マイクロ波工学 基礎と応用”, 学献社, 1993

2) 橋本雅之：“加速試験の進め方・方法とデー夕解析・評価”, 応用技術出版，1992 